Review - Pregledni rad

UDK: 637.112 .2

\title{
Influence of nutrition on the quality of colostrum and milk of ruminants
}

doi: 10.15567/mljekarstvo.2018.0302

\author{
Ewa Pecka-Kiełb ${ }^{*}$, Andrzej Zachwieja ${ }^{2}$,Edyta Wojtas ${ }^{2}$, Wojciech Zawadzki ${ }^{1}$ \\ ${ }^{1}$ Wroclaw University of Environmental and Life Sciences, \\ Department of Biostructure and Animal Physiology, Norwida 31, 50-375 Wroclaw, Poland \\ ${ }^{2}$ Wroclaw University of Environmental and Life Sciences, \\ Department of Cattle Breeding and Milk Production, Chełmońskiego 38c, 51-630 Wroclaw, Poland
}

Received - Prispjelo: 30.08.2017.

Accepted - Prihvaćeno: 18.04.2018.

\begin{abstract}
The composition and properties of mammary glands' secretions are influenced by numerous genetic and environmental factors. Types and quality of the feed and feed additives determine the characteristics and quality of products of animal origin. In terms of quality and quantity, the desired effects may be achieved only when the feed ration fully responds to the needs of the animal. Not supplying the required components with the feed affects the composition of both, colostrum and milk, and reduces their production, which influences health condition of animals and - as a result food safety. Milk and milk products are considered functional food not only due to high nutritional value but also due to positive impact on human health. Nowadays there are various initiatives to produce the so-called healthy food obtained through specially programmed nutrition of animals, which means enriching foodstuffs in biologically active substances. In order to obtain good physicochemical parameters in colostrum and milk of ruminants, it is vital to use high quality feeds in order to satisfy protein and energy demand in animals, and mineral and vitamin contents in the feed ration should be properly balanced. It is also important to use energy additives in dry cows. Another important issue is obtaining the rumen fermentation profile that reduces the emission of methane and determines an appropriate profile of volatile fatty acids. The manuscript is devoted to physiochemical properties of colostrum and milk of cows, goats, sheep as well as the influence of nutrition on the quality of mammary secretions of ruminants.
\end{abstract}

Key words: nutrition, colostrum, milk, ruminants

\section{Introduction}

Physiochemical properties of colostrum and milk of ruminants may be modified by diversified nutrition during the dry period (Pecka et al., 2013). The use of probiotics and prebiotics leads to higher levels of immunoglobulin and minerals such as calcium, phosphorus, zinc and copper in colostrum (Sol Morales et al., 2000; Strusińska et al., 2004). Increased contents of long-chain polyunsaturated omega- 3 fatty acids in feed rations achieved thanks to addition of fish oil or linseed reduce the level of cholesterol in colostrum and milk (Donovan et al., 2000, Kouřimská et al., 2014). Due to growth in genetic potential of animals and in milk yield as well, proper balancing of nutrients and minerals in feed rations becomes more and more important. Additionally, it may cause the transfer of vitamins and minerals to the fetus, and consequently the improved health condition of newborn animals (Zachwieja et al., 2007). The objectives of this study were to determine the biological value of colostrum and milk of cows, goats and sheep, as well as the influence of nutrition on the quality of mammary secretions of ruminants. The problems discussed in this study may be of interest in terms of health and nutrition of both humans and animals. 


\section{Colostrum and milk of ruminants}

Colostrumis generated in the period immediately before and after calving (Boudry et al., 2008). The quality of colostrum in all farm animals is an important factor determining normal growth and development effectiveness of rearing offspring (Daels, 2006). Physicochemical properties of colostrum and milk differ significantly since colostrum is richer in biologically active elements, such as nucleic acids or amino acids derivatives whose concentration changes considerably in the hours and days after parturition. Chemical compounds like fat, protein, lactose, vitamins and minerals are dissolved or suspended in colostrum. Bactericidal and bacteriostatic substances, including lactoperoxidase, lactoferrin, lysozyme and leucocytes, complement its composition (Boudry et al., 2008; Bernabucci et al., 2013). Compared to milk, colostrum is characterized by a larger proportion of polyunsaturated fatty acids (PUFA) and lower proportion of monounsaturated (MUFA) and saturated long-chain fatty acids (SFA) (Zaitsev and Makarova, 2011).

Between the second and the fifth day of lactation, the levels of organic compounds and electrolytes fluctuate and the obtained secretion is often

Table 1. Chemical composition of yak, llama and donkey milk (Chiavari et al., 2005; Riek and Gerken, 2006; Sheng et al., 2008)

\begin{tabular}{ccccc}
\hline & \multicolumn{4}{c}{ Milk composition $(\mathrm{g} / \mathrm{l} 00 \mathrm{~g})$} \\
\hline Species & Dry matter & Protein & Fat & Lactose \\
\hline Yak & 17.78 & 3.51 & 5.80 & 3.9 \\
\hline Llama & 15.61 & 4.23 & 4.70 & 5.93 \\
\hline Donkey & 8.9 & 1.6 & 0.29 & 6.7 \\
\hline
\end{tabular}

called 'transition milk'. Afterwards its composition stabilizes and the fluid becomes "milk" (Boudry et al., 2008; Bernabucci et al., 2013). Milk also contains most of the mentioned biologically active substances present in colostrum, but their concentration is 100 to 1000 times lower (Boudry et al., 2008). The presence of proteins, such as immunoglobulin, lactoferrin, and lysozyme supports the immune system of both animals and humans. Milk and its products are functional foods because they not only have high nutritional value but also positive influence on human health (Visioli and Strata, 2014). The most commonly consumed milk comes from cows, sheep and goats, but in some regions, the milk of yaks, llamas, donkeys and mares is also popular (Silanikove et al., 2016). The chemical composition of mammary gland secretion is different in different animals and in humans (Table 1 and 2).

Protein substances in colostrum and milk are whey proteins and casein. Whey proteins are small globular proteins with the form of molecular dispersion and are difficult to precipitate. They are characterized by high proportion of sulfur-containing amino acids, mostly albumins, immunoglobulins, lactoferrin, lysozyme and the like. In cow milk whey protein constitute $18 \%$ of total milk proteins, while slightly higher amounts are found in sheep and goat milk (20\% and $22 \%$, respectively) (Potočnik et al., 2011). The quality of colostrum relies on its level of immunoglobulins, whereas the quality of milk depends on the concentration of caseins. There are several casein fractions: $\alpha s_{1}{ }^{-}, \alpha s_{2}-, \beta-, \kappa-$ and $\gamma$ - caseins (Damián et al., 2008; Potočnik et al., 2011; Pecka-Kiełb et al., 2016). In the secretion of cow's, sheep's and goat's mammary glands caseins

Table 2. Average chemical composition of colostrum and milk of different animal species and humans (Ciuryk et al., 2004; Zachwieja et al., 2007; Pecka et al., 2012a; Nowak et al., 2012a; Bernabucci et al., 2013; Pecka-Kiełb et al., 2016; Kowalewska-Łuczak et al., 2017)

\begin{tabular}{ccccccccc}
\hline & \multicolumn{3}{c}{ Colostrum composition $(\mathrm{g} / \mathrm{l} 00 \mathrm{~g})$} & \multicolumn{4}{c}{ Milk composition $(\mathrm{g} / \mathrm{l00} \mathrm{g})$} \\
\hline Species & Dry matter & Protein & Fat & Lactose & Dry matter & Protein & Fat & Lactose \\
\hline Cow & 25.8 & 14.9 & 6.7 & 2.5 & 11.91 & 3.31 & 4.9 & 3.94 \\
\hline Goat & 17.9 & 10.24 & 7.73 & 1.93 & 13.2 & 4.1 & 4.5 & 4.4 \\
\hline Sheep & 32.8 & 21.7 & 10.6 & 1,7 & 15.35 & 5.66 & 3.51 & 5.45 \\
\hline Mare & 19.34 & 15.2 & 1.7 & 2.5 & 11.41 & 2.06 & 1.5 & 6.6 \\
\hline Pig & 26.3 & 16.2 & 5.4 & 3.6 & 19.9 & 5.8 & 5.5 & 4.8 \\
\hline Camel & 18.9 & 10.5 & 2.6 & 4.4 & 12.7 & 4.0 & 4.4 & 4.3 \\
\hline Human & 11.5 & 1.6 & 3.3 & 6.8 & 12.0 & 1.3 & 3.8 & 6.9 \\
\hline
\end{tabular}


have the form of micelles. Cow's milk contains the smallest micelles app. $182 \mathrm{~nm}$, sheep milk slightly larger app. $210 \mathrm{~nm}$, while the largest casein micelles are found in goat's milk and are around $260 \mathrm{~nm}$ (McMahon and Oommen, 2008; Potočnik et al., 2011). Also proportions of particular casein fractions depend on the species (Figurel). Theoretically the qualitative composition of cow's milk and colostrum is similar to those of goat's and sheep, but it differs significantly in the quantities of substances dissolved in the milk of the other two species. Also, the physicochemical properties of fat are different, which in turn results in different taste and use in the dairy industry.

\section{The importance of colostrum and milk}

Colostrum is the first food and is a source of passive immunity of newborns due to the concentration of immunoglobulins, which in cattle, sheep, goats and horses do not get into the embryo's bloodstream (Hernández-Castellano et al., 2015). The only means of providing newborns with adequate immunity is feeding them with appropriate amount of colostrum. Colostrum stimulates the digestive system, and through reducing the chances of infections it has positive influence on the metabolism of young mammals (Zachwieja et al., 2007; Nowak et al., 2012a).
In the first 24 hours after parturition, highperformance cows are capable of producing as many as 25 liters of colostrum, 4-6 liters of which are consumed by the calf; sheep and goats produce 0.4-1.3 L of colostrum (Daels, 2006). The surplus of colostrum produced by cows, especially if it is high quality, may be preserved and then used as a source of immunoglobulins, minerals and biologically active substances not only in feeding calves, lambs, kids, or other farm animals, but it may constitute an element of human diet (Huguet et al., 2006; Pecka et al., 2012a; Hyrslova et al., 2016). Lyophilization of colostrum, that is drying it in low temperature and under reduced pressure, is a much better preservation method than spray drying: it does not cause protein denaturation and the degeneration of immunoglobulins is reduced (Elfstrand et al., 2002). After the process of sublimation, the product preserves its organoleptic characteristics, and thanks to its porous structure, it may easily be rehydrated (Elfstrand et al., 2002; Huguet et al.; 2006). In pharmaceutical industry preserved colostrum (for example through lyophilization) is used for the production of probiotics intended for stimulating the human immune system (Hyrslova et al.; 2016). Bovine colostrum is used as food supplement since it has antiatherosclerotic, anticancer and antibacterial properties, it accelerates healing processes and reduces susceptibility to infections as well as the level of oxidative stress since it is a powerful antioxidant. Mammalian colostrum contains high

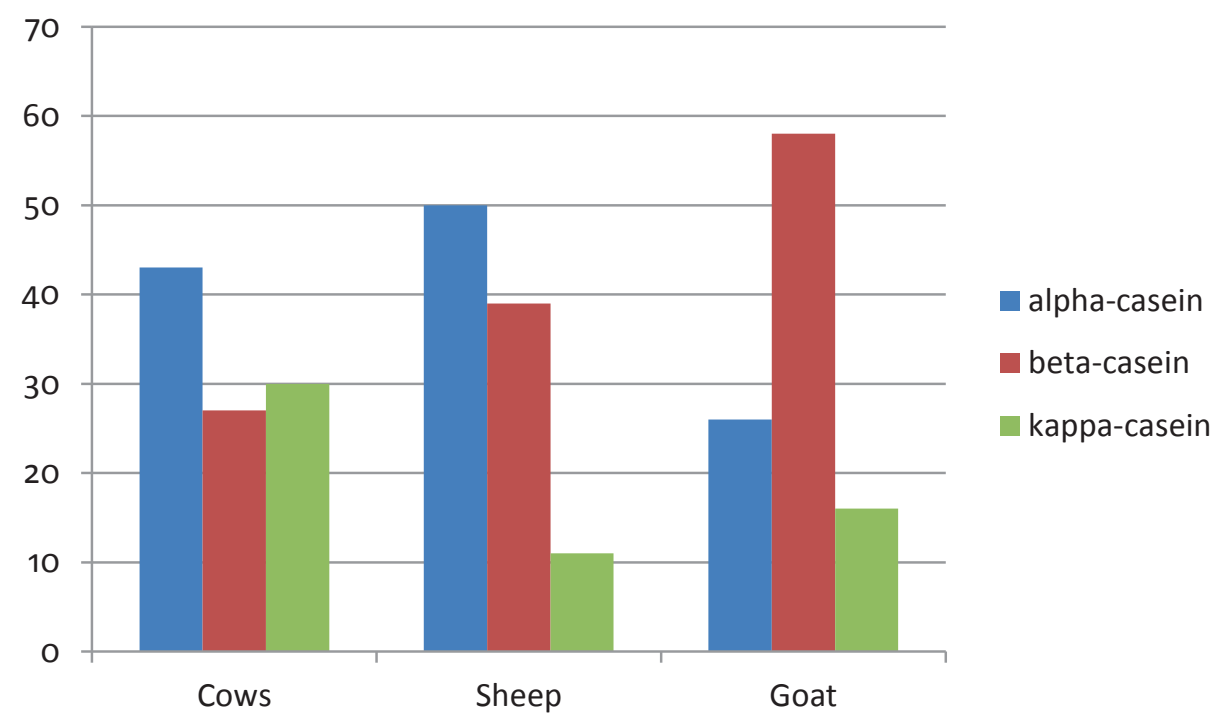

Figurel. Proportions of caseins in cow's, sheep and goat's milk (Damián et al., 2008; Potočnik et al., 2011 ; Pecka-Kiełb et al., 2016) 
levels of insulin-like growth factor (IGF-1), which helps to maintain glucose homeostasis and is highly beneficial for diabetic patients. The activity of IGF-1 is also connected with an increase in insulin sensitivity and a decrease in the hemoglobin Alc level. The use of lyophilized (freeze-dried) colostrum in treatment of patients with type 2 diabetes lowers the level of triglycerides, cholesterol and ketone bodies in blood. Research also suggests that sheep colostrum prevents the development of Alzheimer's disease (Sokołowska et al., 2008).
Mammalian colostrum and milk contain exogenous amino acids. The structure of $\alpha s_{1}{ }^{-}, \alpha s_{2}-, \beta$ - and $\kappa$-casein micelles is made up of calcium phosphate, magnesium and potassium salts, which together with hydrophilic and hydrophobic groups influence their stability (McMahon and Oommen, 2008; Summer et al., 2010). Both whey protein and caseins have specific chemical properties that affect the functioning of animal and human organisms (Table 3).

Table 3. Characteristics of selected protein fractions in colostrum and milk (Rauprich et al., 2000; Conneely, 2001; Lieske et al., 2005; Tripathi and Vashishtha, 2006; Batavani et al., 2007; Park et al., 2007; Boudry et al., 2008; McMahon and Oommen, 2008; Potočnik et al., 2011; Selvaggi et al., 2014)

\begin{tabular}{|c|c|c|c|}
\hline Protein & $\begin{array}{l}\text { Mass } \\
\mathrm{kDa}\end{array}$ & Structure & Properties and significance \\
\hline Serum albumin & 66.3 & $\begin{array}{c}582 \\
\text { amino acids }\end{array}$ & $\begin{array}{l}\text { It is responsible for the regulation of osmotic pressure in blood; } \\
\text { it gets from blood to the secretions of mammary glands in the } \\
\text { process of synthesis of colostrum and milk. }\end{array}$ \\
\hline$\alpha$-lactalbumin & 14.2 & $\begin{array}{c}123 \\
\text { amino acids }\end{array}$ & $\begin{array}{l}\text { This protein is an element of Galacosyltransferase enzyme system } \\
\text { responsible for lactose synthesis. Synthesis of lactose }\end{array}$ \\
\hline$\beta$-lactoglobulin & 18.4 & $\begin{array}{c}162 \\
\text { amino acids }\end{array}$ & $\begin{array}{l}\text { One of its elements is methionine which possesses anticancer proper- } \\
\text { ties. } \beta \text {-lactoglobulin is a specific protein and its consumption may cause } \\
\text { allergies. } \beta \text {-lactoglobulin and } \alpha \text {-lactalbumin are protein fractions vital for } \\
\text { young ruminants - they quickly hydrolyze in the abomasum and are a } \\
\text { good source of free amino acids. }\end{array}$ \\
\hline Immunoglobulins $G$ & $70 \& 23$ & $\begin{array}{l}\text { Monomer, } \\
\text { glycoprotein }\end{array}$ & $\begin{array}{l}\text { Immunoglobulins are transported to mammary gland secretions by } \\
\text { specialized receptors. They are responsible for organism's immunity }\end{array}$ \\
\hline $\begin{array}{l}\text { EGF (epidermal } \\
\text { growth factor) }\end{array}$ & 6 & $\begin{array}{l}53 \\
\text { amino acids, } \\
\text { glycoprotein }\end{array}$ & $\begin{array}{l}\text { EGF prevents translocation of bacteria, that is it limits the passage of } \\
\text { microbial flora through the gastrointestinal wall, } \\
\text { which lowers the probability of infection }\end{array}$ \\
\hline$\alpha$-casein & 25 & \multirow{3}{*}{ Micelles } & $\begin{array}{l}\text { Caseins are hydrated colloidal particles. They are made up of } \\
\text { calcium phosphate, magnesium and potassium salts, which together }\end{array}$ \\
\hline$\beta$-casein & 24 & & \\
\hline$\kappa$-casein & 19 & & $\begin{array}{l}\text { mammals. They are built form amino acids which slowly hydrolyze } \\
\text { protein in the abomasum providing peptides for young animals. }\end{array}$ \\
\hline Lactoferrin & 80 & $\begin{array}{l}692 \\
\text { amino acids, } \\
\text { glycoprotein }\end{array}$ & $\begin{array}{l}\text { Because of its properties, lactoferrin plays an important part } \\
\text { in the absorption of iron through the mucous membrane } \\
\text { of the bowel, participates in the phagocytic activity and has a } \\
\text { considerable influence on the organism's immune response. }\end{array}$ \\
\hline Lysozyme & 14.3 & $\begin{array}{l}129 \\
\text { amino acids, } \\
\text { enzyme }\end{array}$ & $\begin{array}{l}\text { Lysozyme has bactericidal properties. Forming a compound/complex } \\
\text { with lactoperoxidase it stimulates its activity; also } \\
\text { immmunoglobulins enhance lysozyme's activity. Lysozyme penetrates } \\
\text { the outer cell wall of bacteria, thus causing its degeneration. Due to } \\
\text { the differences in the structure of Gram-positive and Gram-negative } \\
\text { bacteria, lysozyme is more effective against Gram-positive bacteria. }\end{array}$ \\
\hline Lactoperoxidase & 78 & glycoprotein & $\begin{array}{l}\text { Lacto peroxidase exhibits bactericidal properties against } \\
\text { Gram-positive bacteria and bacteriostatic properties against Gram- } \\
\text { negative bacteria. Some viruses are sensitive to toxic qualities of this } \\
\text { protein fraction; to fight infections, } \\
\text { it requires an interaction with lactoferrin. }\end{array}$ \\
\hline
\end{tabular}




\section{The influence of nutrition on the composition of} colostrum and milk

The composition and quality of colostrum and milk depend on many genetic and non-genetic factors, such as the animals' breed, lactation period, length of lactation, health condition and maintenance conditions, but predominantly on their nutrition (Moreno-Rojas et al., 1993; Nowak et al., 2012; Zachwieja et al., 2013; Hyrslova et al., 2016). In order to achieve desired results in the colostrum and milk production, both in term of quality and quantity, the feed ration has to fulfill the nutritional requirements of the animal. Failure to provide the necessary nutrients from feed reduces the synthesis of colostrum and milk and influences their quality. Additionally, metabolic process in high-producing dairy cows are intensified compared to other animals, so inadequate nutrition may cause digestive dysfunctions, which leads to diseases affecting the composition of colostrum and milk, as well as animals' productivity (Hamann and Krömker, 1997).

All feeds used in animal farming should have high nutritional value, favorable dietary properties and taste good. The requirement to satisfy the animals' nutritional needs demands perfecting the systems of evaluating nutritional value of feeds and the needs of animals. Nutrition of cattle is the factor allowing to effectively and quickly obtain-compared to other methods-positive changes in the composition and production of colostrum and milk.

\section{Urea level in milk - \\ the indicator of rational nutrition}

One of indicators of adequate nutrition in ruminants is the level of urea in milk showing the level to which the animal's demand for protein is satisfied (Nudda et al., 2009; Papachristiu et al., 2009). The urea content in the secretion of mammary gland is closely correlated to its concentration in the blood serum and allows determination of the proportion of protein and energy metabolism in the rumen and the liver (Abdoun et al., 2006). High urea level with normal level of protein in milk suggests the deficit of energy in the feed ration. In dairy cattle, the standard level of urea in milk ranges from 150 to $300 \mathrm{mg} \mathrm{L}^{-1}$ with the proportion of protein between 3.2 and $3.6 \%$. With the proportion of protein in colostrum at the level of $16 \%$, the level of urea should range between 115 and $200 \mathrm{mg} \mathrm{L}^{-1}$ (Zachwieja et al. 2007). In sheep, the urea level in milk ranges from $153.4 \mathrm{mg} \mathrm{L}^{-1}$ to $217.4 \mathrm{mg} \mathrm{L}^{-1}$ (Kuchtík et al., 2008) while in goats it is much higher $-370 \mathrm{mg} \mathrm{L}^{-1}$ (Nudda et al., 2009).

\section{Condition of animals}

Another indicator of adequate nutrition is the condition of animals. Monitoring the condition of cows is one of the key factors in optimizing the feed ration and preventing metabolic diseases, especially in the periparturient period. The condition of animals directly influences physiological processes connected with production and reproduction, condition of animals and milk yield. Adequate condition of cows before calving on the five-point BCS scale (Body Condition Score) should be 3.5-3.75, during lactation - 2.75 (2.5)-3.25, and 3.25-3.75 in the dry period. The BSC should not fall below 2.5 since the score indicates no energy reserves. During lactation, the changes in BSC should not exceed 1 and the score over 4.24 considerably increases the risk of metabolic dysfunctions. In lactating sheep BSC is between 2.3-2.6 (Papachristiu et al., 2009). In healthy goats BCS ranges between 2.5 and 4; BCS levels of $1.0,1.5$ or 2.0 indicate management or health problems. In these animals BCS levels of 4.5 and 5.0 are rare and usually pertain to show animals (Detweiler et al., 2008).

\section{Products of rumen fermentation}

Technological quality of colostrum and milk is determined by the products of digest fermentation for which microorganisms existing in the rumen are responsible (Figure 2). The main products are volatile fatty acids (VFAs), ammonia and methane. Major VFAs are acetic, propionic and butyric acids. VFAs meet $80 \%$ of demand for energy in animals (Heinhrisch and Varga, 1996). Milk productivity of dairy cows grows together with the VFAs production (Piva et al., 1993). The level of VFAs is correlated with the level of long-chain branching fatty acids in milk (Vlaeminck et al., 2006). Acetic acid created in the rumen is used in the liver to produce ATP. It is also the main source of acetyl-CoA and influences the synthesis of lipids in milk. Propionic acid produced in the rumen is transported to the bloodstream and then to the liver where it serves as precursor to glucose, which in turn is the basic unit for the production of lactose in colostrum and milk. 


\section{Fermentation processes in the rumen result in the production of (among others):}
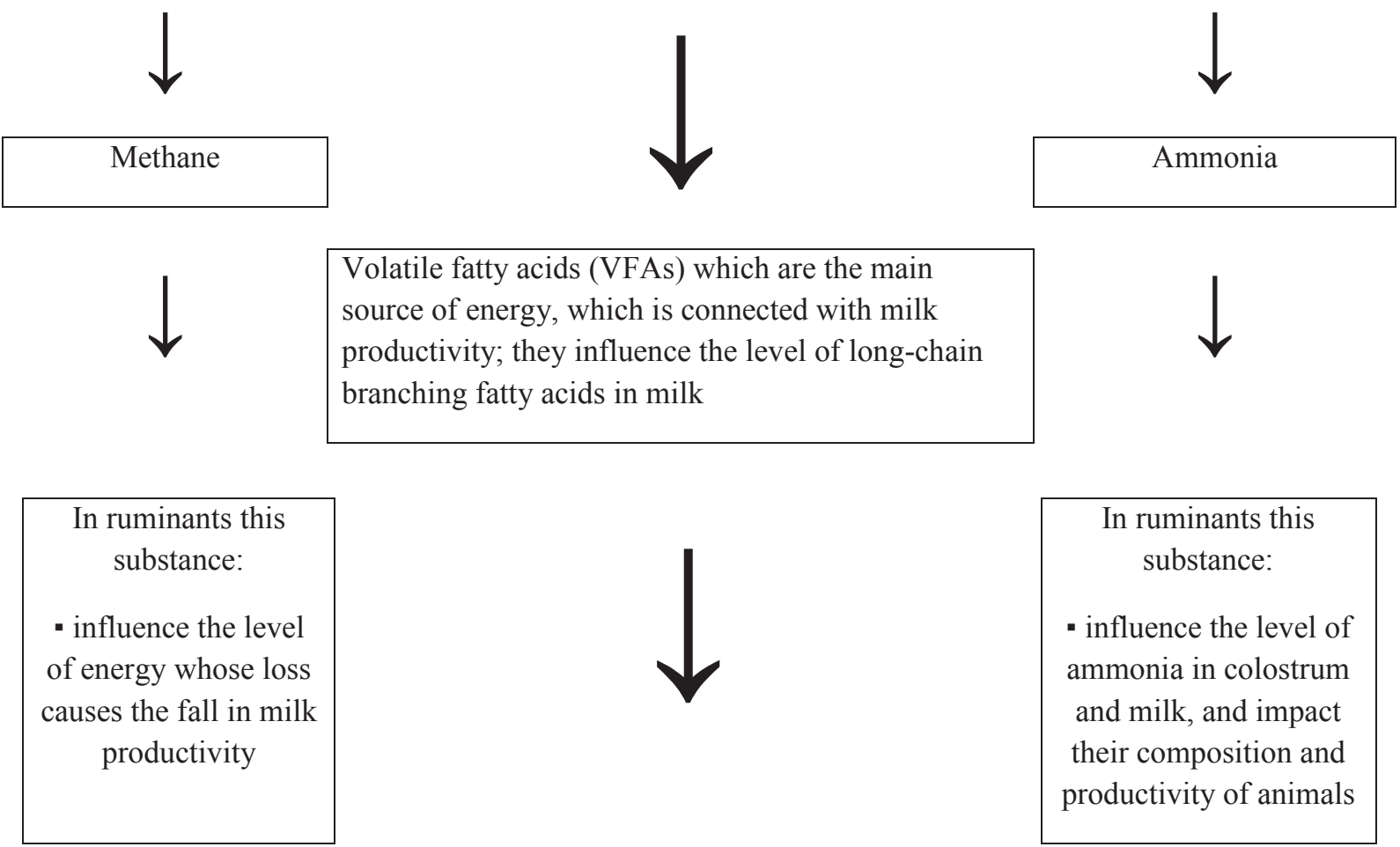

In ruminants this substance:

- influence the level of ammonia in colostrum and milk, and impact their composition and productivity of animals

\begin{tabular}{|c|c|c|c|}
\hline \multicolumn{4}{|c|}{ Volatile fatty acids include: } \\
\hline $\begin{array}{c}\downarrow \\
\text { acetic acid }\end{array}$ & $\begin{array}{c}\downarrow \\
\text { propionic acid }\end{array}$ & $\begin{array}{c}\downarrow \\
\text { butyric acid }\end{array}$ & $\begin{array}{c}\downarrow \\
\text { isobutyric acid, } \\
\text { isovaleric acid }\end{array}$ \\
\hline \multicolumn{4}{|c|}{ In ruminants these substances: } \\
\hline $\begin{array}{l}\quad \downarrow \\
\text { - take part } \\
\text { in the } \\
\text { synthesis } \\
\text { of fat in } \\
\text { colostrum } \\
\text { and milk }\end{array}$ & $\begin{array}{l}\qquad \downarrow \\
\text { - are } \\
\text { precursors of } \\
\text { glucose which } \\
\text { participates in } \\
\text { the production } \\
\text { of lactose in } \\
\text { colostrum and } \\
\text { milk }\end{array}$ & $\begin{array}{l}\qquad \downarrow \\
\text { - influence the } \\
\text { level of energy } \\
\text { whose loss } \\
\text { causes the } \\
\text { decrease in milk } \\
\text { productivity } \\
\text { - influence the } \\
\text { level of ketone } \\
\text { bodies }\end{array}$ & $\begin{array}{l}\qquad \downarrow \\
\text { - prove the activity of } \\
\text { proteolytic bacteria; } \\
\text { degradation of } \\
\text { proteins in the rumen } \\
\text { and their intestinal } \\
\text { digestibility influence } \\
\text { the general content of } \\
\text { protein in colostrum } \\
\text { and milk }\end{array}$ \\
\hline
\end{tabular}

Figure 2. Products of rumen fermentation influencing the quality of colostrum and milk, and animal productivity (Abdoun et al., 2006; Vlaeminck et al., 2006; Yan et al., 2006; Sejian et al., 2011) 
Propionic acid limits fat reserves, increases concentration of triglycerides and insulin, and reduces the threat of hepatic steatosis (Heinhrisch and Varga, 1996). Butyric acid is the precursor of energy and ketone bodies. Isoacids are the result of amino acids catabolism by the rumen microflora, and their presence is the evidence of proteolytic microorganisms' activity (Benedeti et al. 2015). Degradation of protein in the rumen and intestinal digestibility influence its content in colostrum and milk. Ammonia produced in the rumen is toxic for the ruminant, and is therefore transported to the liver and transformed into urea, which partly permeates to milk (Abdoun et al., 2006). The level of urea in milk impacts milk composition and consequently it's technological quality too (Henao-Velásquez et al., 2014).

Increased methanogenesis in the rumen is an adverse phenomenon. Large amount of methane emitted by animals causes loss of energy for animals, and consequently a decrease in milk productivity. Decrease in the ratio of acetic to propionic acid causes the reduction of methane production (Stewart et al., 1997). Nowadays there is a tendency in agriculture to introduce feeds and feed additives that reduce the emission of methane (Yan et al., 2006, Miśta et al., 2014; Pecka-Kiełb et al., 2015). One of the feeds changing the fermentation profile is Dried Distillers Grains with Solubles (DDGS) (Table 4).

\section{Nutrition of dry cows}

There is a correlation between cow's nutrition in the dry period and the quality of colostrum, and later milk, produced by them. Increased demand for energy, protein and minerals in this period is connected with intensive development of the embryo and the production of colostrum. Reduced feed intake in dry cows frequently leads to energy deficiency since they have higher demand for energy. The use of calcium propionate as additive in feed lowers the risk of metabolic diseases after calving. More energy in the feed ration for cows before calving increases the level of glycogen in the liver, which correlates with higher concentration of glucose in the blood. Use of energy increasing additives in feed ration (TMR) has positive impact on metabolic status of transition cows (three weeks before and after calving). Simultaneously, in postparturient cows decreased fat content and yield in the first month of lactation correlated with the tendency to decreased levels of non-esterified fatty acid in the serum (Bakshi et al., 2017, Wankhade et al., 2017)

Higher proportion of starch in the feed results in the acceleration of microbial protein synthesis and, consequently, an increase in the proportion of amino acids absorbed in the small intestine. Because of accelerated propionate fermentation, higher use of starch may lead to maintaining levels of energy

Table 4. Influence of DDGS on the ruminal fermentation in sheep and cows (Miśta et al., 2014; Pecka-Kiełb et al., 2015)

\begin{tabular}{|c|c|c|c|c|c|c|c|}
\hline \multirow{4}{*}{ Fermentation parameters } & \multicolumn{7}{|c|}{$24 \mathrm{~h}$ incubation - rumen digest } \\
\hline & \multicolumn{7}{|c|}{ DDGS inclusion level } \\
\hline & \multicolumn{3}{|c|}{ Sheep } & \multicolumn{4}{|c|}{ Cow } \\
\hline & $\mathrm{C}$ & $10 \%$ & $20 \%$ & $\mathrm{Cl}$ & $\mathrm{Dl}$ & $\mathrm{D} 2$ & D3 \\
\hline Gas production $^{1}$ & 110.21 & 107.78 & 99.71 & 88.08 & 76.98 & 63.94 & 61.17 \\
\hline Methane $^{1}$ & 34.36 & 33.41 & 32.35 & 17.64 & 16.94 & 13.71 & 14.03 \\
\hline Total VFA ${ }^{1}$ & 246.02 & 228.22 & 251.16 & 274.9 & 262.0 & 224.4 & 223.5 \\
\hline \multicolumn{8}{|l|}{$\mathrm{VFA}^{2}:$} \\
\hline Acetate & 63.76 & 63.69 & 62.34 & 50.28 & 51.38 & 49.50 & 50.80 \\
\hline Propionate & 20.84 & 20.90 & 21.87 & 31.51 & 31.04 & 32.86 & 32.50 \\
\hline Butyrate & 10.82 & 10.61 & 10.92 & 10.68 & 10.59 & 10.26 & 9.92 \\
\hline Valerate & 1.50 & 1.42 & 1.50 & 3.73 & 3.64 & 4.05 & 3.70 \\
\hline Caproate & 0.20 & 0.19 & 0.18 & 0.49 & 0.46 & 0.54 & 0.51 \\
\hline
\end{tabular}

C- feed concentrate mixture; $10 \%, 20 \%$ proportion of DDGS in feed concentrate in dry matter; C1- total mixed ration (TMR), D1, D2, D3 - DDGS content of 10, 15 or $20 \%$ of the dry matter; ${ }^{1} \mathrm{mmol} / \mathrm{L}$ of not diluted ruminal fluid; ${ }^{2} \mathrm{~mol} / 100 \mathrm{~mol}$ of total volatile fatty acids (VFA) concentration 
reserves. Part of starch in the rumen is a source of energy for microorganisms which synthesize vital microbial protein. Inclusion of corn seeds in the feed ration - irrespectively of its form - causes an increase in the fat content in milk; the most beneficial is coarsely ground corn, since the digestibility of fiber grows with reduced degradation of starch in the rumen. This in turn increases the flow of starch to the duodenum and the small intestine (so-called bypass starch) and the absorption of glucose in the intestine. Reduced degradation of starch in the intestine is caused by insufficient activity of amylolytic enzymes (amylase and isomaltase), absorption of glucose in the intestinal wall and microbial fermentation of glucose: it increases the proportion of basic milk components, including protein. In cows obtaining part of energy form corn meal, protein content was higher possibly due to its improved use by microbiota and gradual degradation in the rumen. An increase in the rumen starch fermentation is also connected with acceleration of microbial protein synthesis and, in consequence, high-level synthesis of protein in the mammary gland.

One of many methods of raising energy levels is introducing fat in the feed ration causing growth in energy concentration without simultaneous negative changes in the structural to non-structural carbohydrates ratio. The proportion of such additives should not exceed $5 \%$ since they may result in unfavorable changes in the processes taking place in the rumen. These changes may be connected with bacteriostatic activity of fat, inhibition of microbial activity and a reduction in digestibility of structural carbohydrates.

The use of probiotics and prebiotics as additives in the nutrition of preparturient cows may improve the quality of colostrum through increased levels of immunoglobulins. It may also result in a higher content of minerals, i.e. calcium, phosphorus, zinc and cuprum, in colostrum. The use of $\mathrm{Zn}, \mathrm{Cu}$ and $\mathrm{Mn}$ as bioplexes in the transition period increases the level of protein in colostrum (Strusińska et al., 2004). The addition of rumen-protected fats, rapeseed oil and fish oil to feed rations of cows causes an increase in protein and dry matter content, as well as a decrease in somatic cells count and urea content in pre-colostrum secretion and colostrums proper. Increased energy level in the feed ration in the dry period is responsible for a decrease in somatic cells count and fat content with higher levels of lactose and IgM in colostrum.

\section{Feeding and the use of feed additives}

Large proportion of goat's and sheep milk is used for cheese production, so nutrition of the animals during lactation is vital in obtaining the material of good technological parameters. The level of energy and protein in feed influences milk yield and the content of fat and protein. Supplying too little energy in the feed ration leads to a decrease in sheep's milk yield and fat content and an increase in protein proportion. Some feeds and feed additives may improve the quality of milk. For instance, the use of iodine as feed additive increases the content of fat and protein in in sheep milk (Nudda et al., 2009). Reduction of milk yield and fat content in sheep may appear when animals are fed vegetable oil with alfalfa haylage but not when they are fed corn silage. The use of protein-rich feeds, such as soy or fishmeal, results in an increase in protein content in milk.

$90 \%$ of world population of goats is bred in households and does not receive adequate amount of nutrients form feeds. The use of herbs, such as Asparagus racemosus, Nigella sativa, Leptadenia reticulata, and Cuminum cyminum, improves milk quality since herbs stimulate immunity of animals (Mirzami, 2012). The inclusion of Chlorella vulgaris in goat's diet changes the profile of fatty acids. The greatest effect was seen in the relative reduction of palmitic acid content and increased oleic, linoleic, and linolenic acids content (Kouřimská et al., 2014). Because of the proportion of milk production and animal populations most research concerns cows.

Traditionally milk yield and its composition were influenced by diversified, seasonal supply of feeds and changing structures of feed rations for animals. In modern loose housing barns animals are usually fed total mixed ration (TMR) and partially mixed ration (PMR) ad libitum - adequately balanced they may increase milk yield without deteriorating the health of animals and physicochemical properties of milk (Bargo et al., 2002; Januś, 2009). Raw milk obtained from TMR fed herds is usually characterized by higher fat and protein content (including caseins) but it has a smaller proportion of lactose compared to the milk of cows kept in households. Compared to TMR fed cows, pasture-fed dairy cows give milk with high content of $\alpha$-lactalbumin and $\alpha$-casein when given water or feed supplemented with insulin (Król et al., 2011). 
Feeding cows with green fodder from pasture causes an increase in the proportion of caseins and a decrease in whey protein, which results in shortening protein coagulation time and improving cheese productivity. In pasture-fed animals, compared to cows fed TMR, increased proportions of C18:0 and $\mathrm{Cl} 18: 1$ and decreased proportions of $\mathrm{C} 10: 0$ and C14:0 are observed (Donovan et al., 2000).

The use of fish oil rich in conjugated linoleic acid (CLA) in the feed ration for cows decreases the levels of C10:0, C14:0, C14:1, C16:0, C18:0 and increases the proportion of $\mathrm{Cl} 18: 1$ in milk. The addition of flax seed in the feed ration modifies the proportion of fat fractions in milk causing an increase in the content of CLA, linolenic acid (LNA), eicosapentaenic acid (EPA), docosahexaenic acid (DHA) and a decrease in cholesterol level (Donovan et al., 2000; Sol Morales et al., 2000). Larger concentration of microelements such as $\mathrm{Cu}, \mathrm{Zn}, \mathrm{J}$, Se or vitamin $\mathrm{E}$ in the feed ration influences the proportion of fatty acids in the secretions of mammary glands (Sol Morales et al., 2000). Algae (Spirulina platensis) added to TMR cause an increase in milk productivity and larger proportion of monounsaturated fatty acids (MUFA) and smaller proportion of polyunsaturated (PUFA) and saturated (SFA) acids with a simultaneous increase in the ratio of MUFA to SFA in milk.

The use of yeast preparations in feed ration stimulates the development of cellulolytic and proteolytic bacteria in the rumen; these bacteria influence the degradation of acid-detergent fiber and utilization of energy in the feed, which in turn strongly influences milk composition. The use of $56 \mathrm{~g}$ of brewer's yeast per day for each animal results in an increase of protein (from $3.06 \%$ to $3.12 \%$ ) and fat (from $4.33 \%$ to $4.46 \%$ ) content as well as milk yield (from $36.5 \mathrm{~kg}$ to $37.4 \mathrm{~kg}$ ). Moreover, the addition of yeast to TMR for high-productivity cows causes a fall in urea level in the secretion of mammary gland (Lehloenya et al., 2008).

The content of mineral substances in colostrum and milk depends mainly on modifications of feed ration for cows through addition of mineral or mineral vitamin mix. Selenium (Se) or vitamin E deficiency in the feed may result in udder diseases and uterine metritis in cows and, consequently, negatively impact the quality of colostrum and milk (Weiss et al., 1990). Mineral compounds content in the mam- mary gland secretion depends also on the basic milk composition and the proportion of caseins to general protein, which in turn depends on nutrition of animals. Casein structure is made up of water-soluble calcium phosphate, magnesium and potassium salts: caseins are a main source of mineral compounds for newborn calves. Differences in mineral compound content in milk are of vital importance for humans - milk and dairy products are a main source of essential minerals, such as calcium of phosphorus, which constitute basic building material for tooth and bone tissue (Pecka et al., 2012b).

Use of minerals (as chelates), vitamins and yeast in the feed ration had beneficial influence on dry cows. Additives also had positive impact on milk yield. More precisely, a larger daily yield in the experimental groups may be associated with mineral and vitamin content (Strusińska et al., 2004). Feed rations supplemented with chelated minerals combined with vitamins and yeast improved the level of iron and zinc in cow's milk. Higher content of mineral may be the result of better transport and absorption of these elements by the cells of glandular tissue of the udder.

All the changes in milk composition correlate to changes in other physicochemical traits, such as thermostability and coagulation, which strongly determine technological value of milk as raw material (Pecka et al., 2013). Modern animal nutrition proposes supplementing basic feed with various feed additives which stabilize or increase animals' productivity. They may also improve the qualities of colostrum and milk which are beneficial for both animals and humans. Adequate nutrition results in higher quality of raw milk through increasing the level of immunoglobulins in colostrum and improving its technological parameters limiting financial losses for dairy farmers and milk products manufactures.

\section{Conclusions}

The results of research and analysis show that the issue of rational nutrition in the periparturient and lactation periods may be reduced to a few simple rules. These rules concern using high quality feeds, optimizing the concentration of nutrients in feed rations, and fulfilling animals' protein and energy requirements. It is also vital to balance mineral 
and vitamin content of feed rations and introduce feed additives that improve absorption of nutrients. In dairy cows, energy supplements should be used.

The articles analysing the influence of nutrition on the quality of animal products often overlook the process of rumen fermentation which should result in certain proportions of volatile fatty acids and reduced methane emission. The profile of volatile fatty acids conditions the metabolic processes in animals and their performance. Increased methanogenesis in the rumen is disadvantageous: high methane emissions result in energy loss and a decrease in milk production. Also the level of urea in secretions of the mammary gland - mainly in cows - requires careful monitoring since it indicates the proper balance of protein and energy in the feed affects the condition of animals and may reduce the incidence of metabolic diseases.

Optimizing cow, sheep and goat nutrition in all the phases of production cycle should be the main goal of farmers, since it allows for high productivity of animals resulting from their genetic predispositions. It also enables longer usability of animals without deteriorating their health condition. This should ensure the adequate composition of colostrum and raw milk conditioning it physicochemical properties and technological usability which translates into high quality dairy products.

\section{Utjecaj hranidbe na kvalitetu kolostruma i mlijeka preživača}

\section{Sažetak}

Sastav i svojstva sekreta mliječnih žlijezda sisavaca pod utjecajem su brojnih genetskih utjecaja i utjecaja okoliša. Vrsta i kvaliteta krmiva i dodataka krmnim smjesama određuju svojstva i kvalitetu proizvoda životinjskog podrijetla. S aspekta kvalitete i kvantitete željeni učinci mogu se postići samo ukoliko omjeri sastojaka u krmivu potpuno odgovaraju potrebama životinje. Nedostatna opskrba potrebnim nutrijentima utječe na sastav i kolostruma i mlijeka, te umanjuje njihovu proizvodnju, što konačno utječe na zdravstveno stanje životinje a time i na sigurnost hrane. Mlijeko i mliječni proizvodi smatraju se funk- cionalnom hranom ne samo zbog visoke nutritivne vrijednosti, već i zbog povoljnih zdravstvenih učinaka na ljudski organizam. U današnje doba postoji niz inicijativa s ciljem proizvodnje tzv. zdrave hrane, primjenom posebno osmišljene hranidbe životinja, što prije svega podrazumijeva obogaćivanje hrane biološki aktivnim sastojcima. Kako bi se dobila dobra fizikalno-kemijska svojstva kolostruma i mlijeka preživača, nužno je koristiti visokokvalitetna krmiva kojima se zadovoljavaju potrebe životinje za proteinima i energijom, dok omjeri mineralnih tvari i vitamina moraju biti uravnoteženi. Također je važno koristiti dodatke za povećanje energetskog unosa u mliječnih krava. Osim toga, važno je postići mikrofloru buraga koja će omogućiti snižavanje emisije metana, kao i postizanje odgovarajućeg sastava masnih kiselina u mlijeku. Ovaj rad bavi se fizikalno-kemijskim svojstvima kravljeg, kozjeg i ovčjeg kolostruma i mlijeka, kao i utjecajem hranidbe na kvalitetu sekreta mliječnih žlijezda preživača.

Ključne riječi: hranidba, kolostrum, mlijeko, preživači

\section{References}

1. Abdoun, K., Stumpff, F., Martens, H. (2006): Ammonia and urea transport across the rumen epithelium: a review. Animal Health Research Reviews 7 (1-2), 43-59. https://doi.org/10.1017/S1466252307001156

2. Bakshi, M.P.S., Wadhwa, M., Makkar, H.P.S. (2017): Feeding of high-yielding bovines during transition phase. CAB Reviews Perspectives in Agriculture Veterinary Science Nutrition and Natural Resources. https://doi.org/10.1079/PAVSNNR201712006

3. Bargo, F., Muller, L.D., Delahoy, J.E., Cassidy, T.W. (2002): Performance of high producing dairy cows with three different feeding systems combining pasture and total mixed rations. Journal of Dairy Science 85 (11), 2948-2963. https://doi.org/10.3168/jds.S0022-0302(02)74381-6

4. Batavani, R.A., Asri, S., Naebzadeh, H. (2007): The effect of subclinical mastitis on milk composition in dairy cows. Iranian Journal of Veterinary Research, University of Shiraz 8 (3), 205-211.

5. Benedeti, B.P.D., Galoro da Silva, L., Marostegan, E.P., Shenkoru, T., Inacio, M.M., Monteiro, H.F., Amorati, B., Yeh, Y., Poulson, RS., Blachier APF. (2015): Effects of partial replacement of corn with glycerin on ruminal fermentation in a dual-flow continuous culture system. PLoS One 23, https://doi.org/10.1371/journal. pone.0143201 
6. Bernabucci, U., Basiricò, L., Morera, P. (2013): Impact of Hot Environment on colostrum and milk composition. Cellular and Molecular Biology 59 (1), 67-83.

7. Boudry, C., Dehoux, J., Portetelle, D., Buldgen, A. (2008): Bovine colostrum as a nature growth promoter for newly weaned piglets: a review. Biotechnology Agronomy, Society and Environment 12 (2), 157-170.

8. Chiavari, C., Coloretti, F., Nanni, M., Sorrentino, E., Grazia, L. (2005): Use of donkey's milk for a fermented beverage with Lactobacilli. Lait 85(6), 481-90. https://doi.org/10.1051/lait:2005031

9. Ciuryk, S., Molik, E., Kaczor, U., Bonczar, G. (2004): Chemical composition of colostrum and milk of Polish Merino sheep lambing at different times. Archiv Tierzucht Dummerstorf 47, 129-134.

10. Conneely, O.M. (2001): Antiinflammatory activities of lactoferrin. Journal of the American Collage of Nutrition 20 (5), 389-395. https://doi.org/10.1080/07315724.2001.10719173

11. Daels, P. F. (2006): Induction of Lactation and Adoption of the Orphan Foal. $8^{\text {th }}$ AAEP Annual Resort Symposium, January 2006; Rome. Italy 19-21

12. Damián, J.P., Sacchi, I., Reginensi, S., Lima, D., Bermúdez, J. (2008): Cheese yield, casein fractions and major components of milk of Saanen and Anglo-Nubian dairy goats. Arquivo Brasileiro de $\mathrm{Me}$ dicina Veterinária e Zootecnia 60 (6), 1564-1569. https://doi.org/10.1590/S0102-09352008000600040

13. Detweiler, G., Gipson T., Merkel R. C., Goetsch A., Sahlu T. (2008): Body Condition Scores in Goats. Pages 127-133 in Proc. 23rd Ann. Goat Field Day, Langston University, Langston, OK.

14. Donovan, D.C., Schingoethe, D.J., Baer, R.J., Ryali, J., Hippen, A.R., Franklin, S.T. (2000): Influence of dietary fish oil on conjugated linoleic acid and other fatty acids in milk fat from lactating dairy cows. Journal of Dairy Science 83 (11), 2620-2628. https://doi.org/10.3168/jds.S0022-0302(00)75155-1

15. Elfstrand, L., Lindmark-Månsson, H., Paulsson, M., Nyberg, L., Ákesson, B. (2002): Immunoglobulins, growth factors and growth hormone in bovine colostrum and the effect of processing. International Dairy Journal 12 (11), 879-887. https://doi.org/10.1016/S0958-6946(02)00089-4

16. Hamann, J., Krömker, V. (1997): Potential of specyfic milk composition variables for cow health management. Livestock Production Sciences 48 (3), 201-208. https://doi.org/10.1016/S0301-6226(97)00027-4

17. Heinhrisch, J., Varga, G. (1996): From Feed to Milk: Understanding Rumen Function, PART I: Background in basic nutrition of dairy cattle 1-12.

18. Henao-Velasquez, A.F., Munera-Bedoya, O.D., Herrera, A.C., Agudelo-Trujillo, J.H., Ceron-Munoz, MF. (2014): Lactose and milk urea nitrogen: fluctuations during lactation in Holstein cows. Revista Brasileira de Zootecnia 43 (9), 479-484. https://doi.org/10.1590/S1516-35982014000900004
19. Hernández-Castellano, LE., Morales-delaNuez, A, Sánchez-Macías, D., Moreno-Indias, I., Torres, A., Capote, J., Argüello, A., Castro, N. (2015): The effect of colostrum source (goat vs. sheep) and timing of the first colostrum feeding ( $2 \mathrm{~h}$ vs. $14 \mathrm{~h}$ after birth) on body weight and immune status of artificially reared newborn lambs. Journal of Dairy Science 98 (1), 204-210. https://doi.org/10.3168/jds.2014-8350

20. Huguet, A., Séve, B., Dividich, J.L., Huërou-Luron, I. (2006): Effect of bovine colostrum-suplemented diet on some gut parameters in weaned piglets. Reproduction Nutrition Development 46 (2), 167-178. https://doi.org/10.1051/rnd:2006006

21. Hyrslova, S., Krausova, G., Bartova, J., Kolesar, L., Curda, L. (2016): Goat and bovine colostrum as a basis for new probiotic functional foods and dietary supplements. Journal of Microbial and Biochemical Technology 8 (2), 056-059.

22. Januś, E. (2009): Urea level in cow's milk fed on total mixed relation (TMR) and traditional system in summer and winter season. Journal Central European Agriculture 10 (1), 33-40.

23. Kouřimská, L., Vondráčková, E., Fantová, M., Nový, P., Nohejlová, L., Michnová, K. (2014): Effect of feeding with algae on fatty acid profile of goat's milk. Scientia Agriculturae Bohemica 45 (3), 162-169. https://doi.org/10.2478/sab-2014-0103

24. Kowalewska-Łuczak, I., Czerniawska-Piątkowska, E., Pecka-Kiełb, E. (2017): Investigation on relationshops od the FABP3 and SLC27A3 genes with milk production traits in sheep. Journal of Elementology 22 (4), 1485-1493

25. Krauze, A. (2015): Alergia na białko mleka krowiego -postacie kliniczne (Cow milk allergy - Clinical approach). Alergia Astma Immunologia 20 (1), 12-16.

26. Król, B. (2011): Effect of mannanoligosaccharides, inulin and yeast nucleotides added to calf milkreplacers on rumen microflora, level of serum immunoglobulin and health condition of calves. Electronic Journal of Polisch Agricultural Universities 14 (2), 1-18.

27. Kuchtík, J., Šustová, K., Urban, T., Zapletal, D. (2008): Effect of the stage of lactation on milk composition, its properties and the quality of rennet curdling in East Friesian ewes. Czech Journal of Animal Science 53 (2), 55-63. https://doi.org/10.17221/333-CJAS

28. Lehloenya, K.V., Stein, D.R., Allen, D.T., Selk, G.E., Jones, D.A., Aleman, M.M., Rehberger, T.G., Mertz, K.J., Spicer, L.J. (2008): Effects of feeding yeast and propionibacteria to dairy cows on milk yield and components, and reproduction. Journal of Animal Physiology and Animal Nutrition 92 (2), 190-220. https://doi.org/10.1111/j.1439-0396.2007.00726.x

29. Lieske, B., Jantz, A., Finke B. (2005): An improved analytical approach for the determination of bovine serum albumin in milk. Dairy Science and Technology 85, 237-248. https://doi.org/10.1051/lait:2005018 
30. McMahon, D.J., Oommen, B.S. (2008): Supramolecular Structure of the Casein Micelle. Journal of Dairy Science 91 (5), 709-1721. https://doi.org/10.3168/jds.2007-0819

31. Mirzami, F. (2012): Effect of herbal feed additives on performance parameters of ruminants and especially on dairy goat: A Review. International Journal for Agro Veterinary and Medical Sciences 6 (5), 307-331. https://doi.org/10.5455/ijavms.137

32. Miśta, D., Pecka, E., Zachwieja, A., Zawadzki, W., Bodarski, R., Paczyńska, K., Tumanowicz, J., Kupczyński, R., Adamski, M. (2014): In vitro ruminal fluid fermentation as influenced by corn-derived dried distillers' grains with solubles. Folia Biologica (Krakow) 62 (4), 345-351. https://doi.org/10.3409/fb62_4.345

33. Moreno-Rojas, R., Amaro - Lopez, M.A., Zurera- Cosano, G. (1993): Mikronutrients in natural cow, ewe and goat milk. International Journal of Food Sciences \& Nutrition 44 (1), 37-46. https://doi.org/10.3109/09637489309017421

34. Nowak, W., Mikuła, R., Kasprowicz-Potocka, M., Ignatowicz M., Zachwieja A., Paczyńska K., Pecka E. (2012): Effect of cow nutrition in the far-off period on colostrum quality and immune response of calves. Bulletin of the Veterinary Institute in Pulawy, 56 (2), 241-246. https://doi.org/10.2478/v10213-012-0043-z

35. Nowak, W., Mikuła, R., Zachwieja, A., Paczyńska, K., Pecka, E., Drzazga, K., Ślósarz, P. (2012a): The impact of cow nutrition in the dry period on colostrum quality and immune status of calves. Polish Journal of Veterinary Sciences 15 (1), 77-82. https://doi.org/10.2478/v10181-011-0117-5

36. Nudda, A., Battacone, G., Decandia, M., Acciaro, M., Aghini-Lombardi, F., Frigeri, M., Pulina, G. (2009): The effect of dietary iodine supplementation in dairy goats on milk production traits and milk iodine content. Journal of Dairy Sciences 92 (10), 5133-5138. https://doi.org/10.3168/jds.2009-2210

37. Papachristou, T.G., Parissi, Z.M., Ben Salem, H., Morand-Fehr, P. (2009): Nutritional and foraging ecology of sheep and goats. (Options Méditerranéennes: Série A. Séminaires Méditerranéens; (85) Zaragoza: CIHEAM / FAO / NAGREF; 399 -403.

38. Park, Y.W., Juárez, M., Ramos, M., Haenlein, G.F.W. (2007): Physico-chemical characteristics of goat and sheep milk. Small Ruminant Research 68 (1-2), 88-113. https://doi.org/10.1016/j.smallrumres.2006.09.013

39. Pecka, E., Dobrzański, Z., Zachwieja, A., Szulc, T., Czyż, K. (2012a): Studies of composition and major protein level in milk and colostrum of mares. Animals Science Journal 83 (2), 162-168. https://doi.org/10.1111/j.1740-0929.2011.00930.x

40. Pecka, E., Zachwieja, A., Góralska-Kowalska, M. (2012b): Level of selected macroelements and selenium in colostrum of cows depending on their age and amount of somatic cells. Przemyst Chemiczny 91 (5), 926-928.

41. Pecka, E., Zachwieja, A., Tumanowicz, J. (2013): Technological parameters of milk depending on the cow housing system, nutrition system, age and number of somatic cells. Przemyst Chemiczny 92 (6), 1087-1091.
42. Pecka-Kiełb, E., Vasil, M., Zachwieja, A., Zawadzki, W., Elecko, J., Zigo, F., Illek, J., Z., Farkašova, Z. (2016): An effect of mammary gland infection caused by Streptococcus uberis on composition and physicochemical changes of cows' milk. Polish Journal of Veterinary Sciences 19 (1), 49-55. https://doi.org/10.1515/pjvs-2016-0007

43. Pecka-Kiełb, E., Zawadzki, W., Zachwieja, A., Michel, O., Mazur, M., Miśta, D. (2015): In vitro study of the effect of corn dried distillers grains with solubles on rumen fermentation in sheep. Polish Journal of Veterinary Sciences 18 (4), 751-758. https://doi.org/10.1515/pjvs-2015-0097

44. Piva, G., Belladonna, S., Fusconi, G., Sicbaldi, F. (1993): Effects of yeast on dairy cow performance, ruminal fermentation, blood components, and milk manufacturing properties. Journal of Dairy Sciences 76 (9), 2717-22. https://doi.org/10.3168/jds.S0022-0302(93)77608-0

45. Potočnik, K., Gantner, V., Kuterovac, K., Cividini A. (2011): Mare's milk: composition and protein fraction in comparison with different milk species. Mljekarstvo 61 (2), 107-113.

46. Rauprich, A.B.H., Hammon, J., Blum, W. (2000): Influence of feeding different amounts of first colostrums on metabolic, endocrine, and health status and on growth performance in neonatal calves. Journal of Animal Science 78 (4), 896-908. https://doi.org/10.2527/2000.784896x

47. Riek, A., Gerken, M. (2006): Changes in llama (Lama glama) milk composition during lactation. Journal of Dairy Sciences 89, 3484-93. https://doi.org/10.3168/jds.S0022-0302(06)72387-6

48. Sejian, V., Lal, R., Lakritz, J., Ezeji, T. (2011): Measurement and prediction of enteric methane emission. International Journal of Biometeorology 55 (1), 1-16. https://doi.org/10.1007/s00484-010-0356-7

49. Selvaggi, M., Laudadio, V., Dario, C., Tufarelli, V. (2014): Investigating the genetic polymorphism of sheep milk proteins: a useful tool for dairy production. Journal Sciences Food and Agriculture 94 (15), 3090-3099. https://doi.org/10.1002/jsfa.6750

50. Sheng, Q. Li, J., Alam, MS., Fang, X., Guo, M. (2008): Gross composition and nutrient profiles of Chinese yak (Maiwa) milk. International Journal of Food Sciences \& Technology 43, 568-72. https://doi.org/10.1111/j.1365-2621.2006.01463.x

51. Silanikove, N., Leitner, G., Merin, U. (2016): Influence of animal health, breed, and diet on non-cow milk composition in book: non-bovine milk and milk products, $\mathrm{p}$. 61-79.

52. Sokołowska, A., Bednarz, R., Pacewicz, M., Georgiades, J.A., Wilusz, T., Polanowski, A. (2008): Colostrum from different mammalian species - a rich source of colostrinin. International Dairy Journal 18 (2), 204-209. https://doi.org/10.1016/j.idairyj.2007.08.004

53. Sol Morales, M., Palmquist, D.L., Weiss, W.P. (2000): Milk fat composition on Holstein and Jersey cows with control or depleted copper status and fed whole soybeans or tallow. Journal of Dairy Science 83 (9), 2112-2119. https://doi.org/10.3168/jds.S0022-0302(00)75093-4 
54. Stewart, C.S., Flint, H.J., Byrant, M.P. (1997): The rumen bacteria. In: Hobson, P.N., Stewart, C.S. The Rumen Microbial Ecosystem, 2 ${ }^{\text {nd }}$ ed. Blackie Academic and Professional, USA. New York; p. 10-55. https://doi.org/10.1007/978-94-009-1453-7_2

55. Strusińska, D., Mierzejewska, J., Skok, A. (2004): Concentration of mineral components $\beta$-carotene, vitamins $\mathrm{A}$ and $\mathrm{E}$ in cow colostrum and milk when using mineralvitamin supplements. Medycyna Weterynaryjna 60 (2), 202-206.

56. Summer, A., Santus, E., Casanova, L., Joerg, H., Rossoni, A., Nicoletti, C., Donofrio, G., Mariani, P., Malacarne, M. (2010): Short communication: Characterization of monoclonal antybody for $\kappa$-casein B of cow's milk. Journal of Dairy Science 93 (2), 796-800. https://doi.org/10.3168/jds.2009-2636

57. Tripathi, V., Vashishtha, B. (2006): Bioactive compounds of bovine colostrums. Food Reviews International 22 (3), 225-244. https://doi.org/10.1080/87559120600694606

58. Visioli, F., Strata, A. (2014): Milk, dairy products, and their functional effects in humans: a narrative review of recent evidence. Advances and Nutrition 5 (2), 131-143. https://doi.org/10.3945/an.113.005025

59. Vlaeminck, B., Fievez, V., Tamminga, S., Dewhurst, R.J., Vuuren, A., De Brabander, E., Demeyer D. (2006): Milk Odd- and Branched-Chain Fatty Acids in Relation to the Rumen Fermentation Pattern. Journal of Dairy Science 89 (10), 3954-3964. https://doi.org/10.3168/jds.S0022-0302(06)72437-7
60. Wankhade, P.R., Manimaran, A., Kumaresan, A., Jeyakumar, S., Ramesha, K.P., Sejian, V., Rajendran, D., Varghese, M.R. (2017): Metabolic and immunological changes in transition dairy cows: A review. Veterinary World (11), 1367-1377. https://doi.org/10.14202/vetworld.2017.1367-1377

61. Weiss, W.P., Hogan, J.S., Smith, K.L., Hoblet, K.H. (1990): Relationships Among Selenium, Vitamin E, and Mammary Gland Health in Commercial Dairy Herds. Journal of Dairy Sciences. 73 (2), 381-390. https://doi.org/10.3168/jds.S0022-0302(90)78684-5

62. Yan, T., Mayne, S., Porter, M.G. (2006): Effects of dietary and animal factors on methane production in dairy cows offered grass silage-based diets. International Congress Series. 1293, 123-126. https://doi.org/10.1016/j.ics.2006.02.024

63. Zachwieja, A., Kupczynski, R., Bodarski, R., Paczynska, K., Mista, D., Pecka, E., Zawadzki, W., Tumanowicz, J., Adamski, M. (2013): Dry distillers grains with solubles from bioethanol production as a dietary additive used in feeding ruminants. Przemyst Chemiczny 92 (6), 10501055.

64. Zachwieja, A., Szulc, T., Potkańska, A., Mikuła, R., Kruszyński, W., Dobicki, A. (2007): Effect of different FAT supplements uses during dry period of cows on colostrum physico-chemical properties. Biotehnology in Animals Husbandry 23 (5,6-2), 67-75.

65. Zaitsev, S.Y., Makarova, T.B. (2011): Change in the fatty acid composition of black pied cows' colostrum and milk during parturient paresis. Russian Agriculturaly Sciences 37, 249-251. https://doi.org/10.3103/S1068367411030220KA 